Section Editor

John J. Millichap, MD

Teaching NeuroImages:

\title{
Severe vasospasm in traumatic brain injury
}

Michael Reznik, MD

Yumna Saeed, MD

Lori Shutter, MD

Correspondence to

Dr. Shutter:

shutterla@upmc.edu
A 45-year-old man had a severe traumatic brain injury (TBI) with multicompartmental hemorrhages (figure 1). He was initially noted to be awake and following commands with his right side. Two weeks later, his examination deteriorated to coma with flaccid quadriplegia. Initial workup, including EEG, was unrevealing. MRI brain showed new multiterritorial infarcts (figure 1); a catheter-based angiogram confirmed severe vasospasm in several large vessels (figure 2).

Vasospasm following TBI has been previously described as underrecognized because it is often clinically silent, and typically occurring in the first several days when symptomatic. ${ }^{1,2}$ Late and extreme cases, as above, are rarely described.

\section{AUTHOR CONTRIBUTIONS}

Download teaching slides: Neurology.org revising the manuscript. Dr. Shutter: study design, analysis/interpretation of the data.

\section{STUDY FUNDING}

No targeted funding reported.

\section{DISCLOSURE}

The authors report no disclosures relevant to the manuscript. Go to Neurology.org for full disclosures.

\section{REFERENCES}

1. Oertel M, Boscardin WJ, Obrist WD, et al. Posttraumatic vasospasm: the epidemiology, severity, and time course of an underestimated phenomenon: a prospective study performed in 299 patients. J Neurosurg 2005;103: 812-824.

2. Kramer DR, Winer JL, Pease BA, Amar AP, Mack WJ. Cerebral vasospasm in traumatic brain injury. Neurol Res Int 2013;2013:415813.
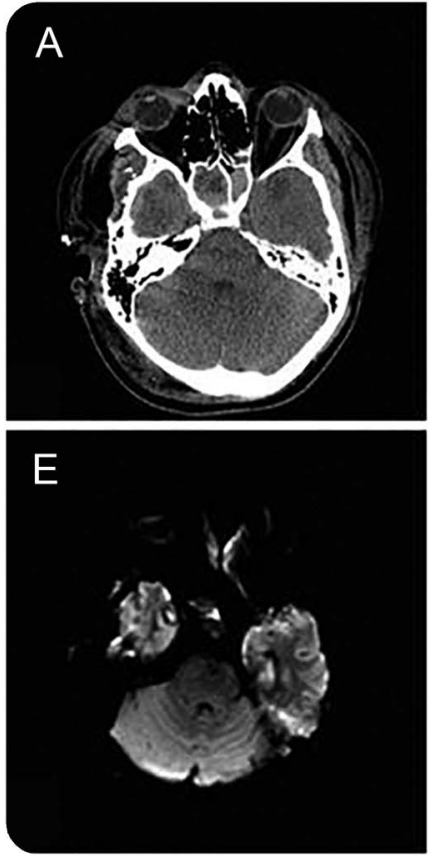
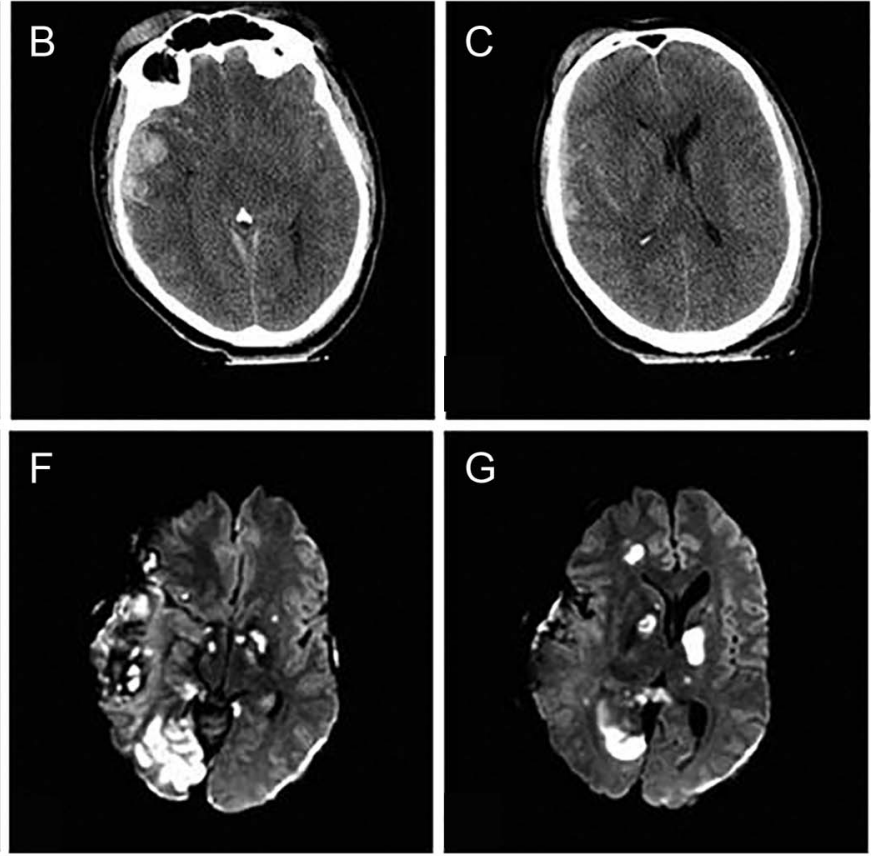
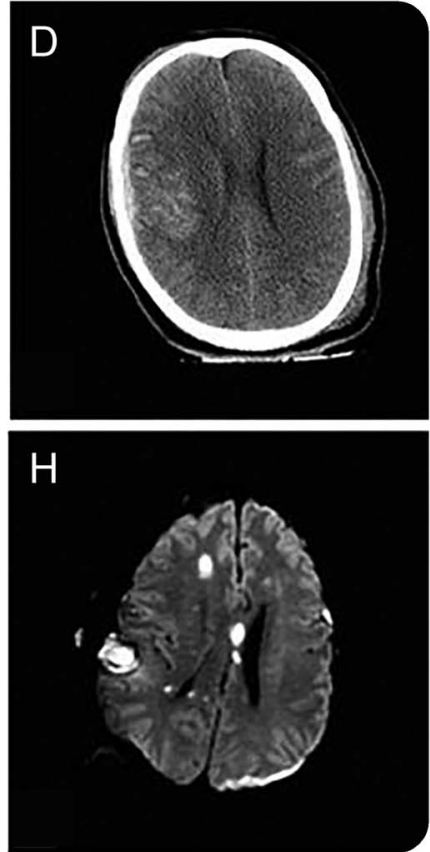

Admission head CT shows right temporal contusion (B-C) with bilateral subarachnoid hemorrhage (B-D). Axial diffusion-weighted imaging 2 weeks later shows new infarcts in the right frontal lobe ( $G$ and $H)$, bilateral deep nuclei and splenium of the corpus callosum (G), and right occipital lobe (F and $G)$, while sparing the brainstem $(\mathrm{E})$; prior right temporal contusion, subdural and subarachnoid hemorrhages, and areas of axonal injury are also noted.

From the Department of Neurology, University of Pittsburgh Medical Center, PA. 


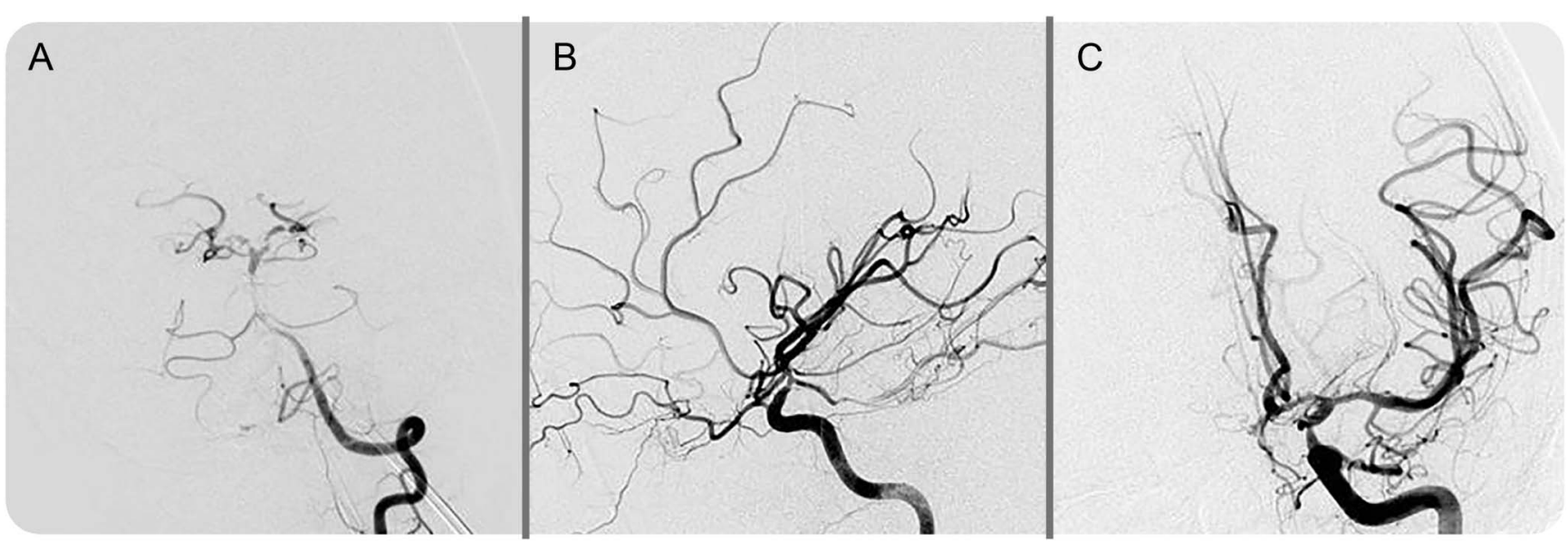

Catheter-based angiogram shows severe vasospasm of the basilar (A), bilateral posterior cerebral (A), right internal carotid (B), and left internal carotid arteries (C). 


\section{Neurology}

\section{Teaching NeuroImages: Severe vasospasm in traumatic brain injury \\ Michael Reznik, Yumna Saeed and Lori Shutter \\ Neurology 2016;86;e132-e133 \\ DOI 10.1212/WNL.0000000000002482}

\section{This information is current as of March 21, 2016}

\section{Updated Information \& Services}

\section{Supplementary Material}

\section{References}

Subspecialty Collections

Permissions \& Licensing

\section{Reprints}

including high resolution figures, can be found at: http://n.neurology.org/content/86/12/e132.full

Supplementary material can be found at: http://n.neurology.org/content/suppl/2016/03/19/WNL.0000000000002 482.DC1

This article cites 2 articles, 0 of which you can access for free at: http://n.neurology.org/content/86/12/e132.full\#ref-list-1

This article, along with others on similar topics, appears in the following collection(s):

All Cerebrovascular disease/Stroke http://n.neurology.org/cgi/collection/all_cerebrovascular_disease_strok

\section{Brain trauma}

http://n.neurology.org/cgi/collection/brain_trauma

Critical care

http://n.neurology.org/cgi/collection/critical_care

Infarction

http://n.neurology.org/cgi/collection/infarction

Other cerebrovascular disease/ Stroke

http://n.neurology.org/cgi/collection/other_cerebrovascular_disease_s troke

Information about reproducing this article in parts (figures,tables) or in its entirety can be found online at:

http://www.neurology.org/about/about_the_journal\#permissions

Information about ordering reprints can be found online:

http://n.neurology.org/subscribers/advertise

Neurology ${ }^{\circledR}$ is the official journal of the American Academy of Neurology. Published continuously since 1951 , it is now a weekly with 48 issues per year. Copyright @ 2016 American Academy of Neurology. All rights reserved. Print ISSN: 0028-3878. Online ISSN: 1526-632X.

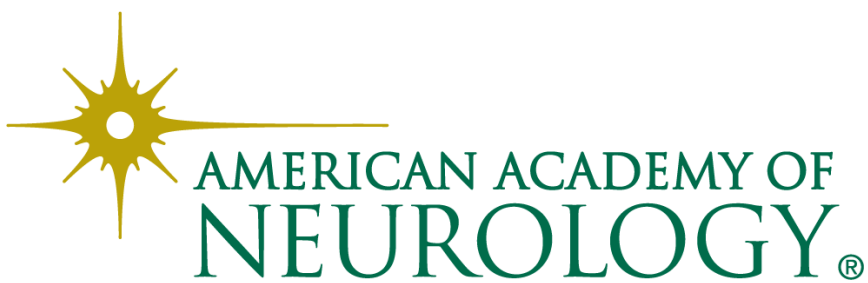

